\title{
KETAHANAN PANGAN KELUARGA ORANG RIMBA SELATAN TAMAN NASIONAL BUKIT DUA BELAS JAMBI: STUDI MIKROETNOGRAFI KELUARGA NJALO DALAM MENGHADAPI PANDEMIK
}

\author{
Kristiawan( $\left({ }^{*}\right)$, Adi Prasetijo (2), Dwi Sutiningsih ( $\left.{ }^{\beta}\right)$ \\ ${ }^{1}$ Magister of Epidemiology, Graduate School, Universitas Diponegoro, Semarang, Indonesia. \\ ${ }^{2}$ Department of Anthropology, Faculty of Humanities, Universitas Diponegoro, Semarang, Indonesia. \\ ${ }^{3}$ Magister of Epidemiology, Graduate School, Universitas Diponegoro, Semarang, Indonesia.
}

\begin{tabular}{ll} 
ARTICLE INFORMATION \\
\hline Submitted & $: 12^{\text {th }}$ December, 2020 \\
Review & $: 14^{\text {th }}$ April, 2021 \\
Accepted & $: 20^{\text {th }}$ May, 2021 \\
Published & $: 07^{\text {th }}$ June, 2021 \\
Available Online & $:$ June, 2021
\end{tabular}

\section{KEYWORDS}

Food security; Orang Rimba; Covid19.

\section{CORRESPONDENCE}

*E-mail: cristiawan82@gmail.com

\begin{abstract}
A B S T R A C T
The Orang Rimba are a hunting-gathering group that lives depending on the availability of the forest. Forests not only function as livelihoods but also have cultural significance as a resource for their cultural traditions. However, in the last few decades, forest conversion in Jambi province has increased. The increased function of forests in Jambi from forests as plantation areas, mining areas and industrial plantation forest areas has made the lives of the Orang Rimba as a hunting-gathering group increasingly threatened. Food security is a condition in which all people, at any time, have access both physically, socially, and economically to adequate, safe, and nutritious food which can meet food needs and food preferences for an active and healthy life. Through the micro ethnography approach, the purpose of this paper is to know and understand the phenomenon of food security from the perspective of the Orang Rimba as seen from its availability, adequacy, affordability, and security. Orang Rimba have food security by relying on food sources available in the forest. In a state of urgency they will return to the forest.
\end{abstract}

\section{A. PENDAhUluan}

$\mathrm{K}$ etahanan pangan merupakan salah satu isu yang juga menjadi perhatian negara-negara di belahan dunia selain fokus pada pemutusan rantai penyebaran wabah Covid-19. Pandemik Covid19 telah menimbulkan beberapa kondisi seperti berkurangnya pasokan makanan, perubahan konsumsi makanan dan pola distribusi makanan yang tidak berjalan optimal (Khairunnisa 2020). Situasi tersebut terjadi sebagai dampak ikutan dari usaha pemutusan rantai penyebaran wabah Covid19.

Situasi kerawanan dan ketahanan pangan juga terjadi pada kelompok masyarakat berburu meramu yang hidupnya sangat tergantung dari hutan. Salah satu kelompok masyarakat berburu dan meramu yang masih eksis sampai saat ini adalah Orang Mereka tersebar di beberapa wilayah hutan dataran rendah di Provinsi Jambi. Umumnya sumber Rimba atau disebut juga sebagai Suku Anak Dalam.

penghidupan Orang Rimba bersumber dari aktivitas berburu dan meramu. Beberapa literatur bahkan menyebutkan bahwa mereka adalah economic hunter-gatherer yang mengantungkan hidupnya dari aktivitas ekonomi yang berbasiskan pertukaran sumber daya alam (Prasetijo 2017b). Pada situasi pandemik Covid 19 ini, kebijakan pembatasan sosial juga memberikan tekanan yang cukup besar bagi ketahanan pangan Orang Rimba.

Saat ini sebagian besar kelompok Orang Rimba telah hidup di luar hutan. Terusirnya mereka dari dalam hutan karena maraknya aktivitas illegal logging, pertambangan dan dampak dari bencana kebakaran hutan dan lahan. Berdasarkan analisa citra Lansat TM 8, luasan tutupan hutan di Jambi tahun 2019 hanya berkisar 900 ribu hektar, atau sekitar $17 \%$ dari total luas wilayah Jambi. Luasan tutupan hutan ini menurun sebesar 20 ribu hektar dari analisa citra tahun 2017 (Komunitas Konservasi Indonesia (KKI) Warsi 2019). Setelah luasan hutan semakin berkurang, Orang Rimba menghadapi persoalan hilangnya asset sebagai sumber 
penghidupan mereka. Dalam banyak kasus, persoalan hilangnya asset ini membuat Orang Rimba kesulitan untuk memenuhi kesinambungan kecukupan pangan mereka sehingga mereka menghadapi kerentanan dalam penyediaan pangan.

Fungsi aset tidak hanya untuk fungsi produksi, namun juga mempunyai fungsi kultural yang sangat kuat (Prasetijo 2017a). Fenomena Orang Rimba yang telah kehilangan asset dapat dilihat pada masyarakat Orang Rimba yang tersebar di Sepanjang Jalan Lintas Sumatra, Selatan Taman Nasional Bukit Tiga Puluh dan Orang Rimba yang berada di sekitar kawasan Taman Nasional bukit Dua Belas (Prasetijo 2011). Meskipun sebagian besar Orang Rimba hidup pada tempat yang tidak berhutan lagi, sumber penghidupan mereka masih berasal dari aktivitas berburu dan meramu.

Pada tahun 2015 terdapat kasus 11 kematian anggota kelompok Orang Rimba di sekitar Kawasan Taman Nasional Bukit Dua Belas (TNBD) karena kelaparan dan terserang penyakit, dimana hal ini menunjukan bahwa kerentanan mereka akan pangan sangat nyata (Tambunan 2015). Sebagai akibat kondisi kelaparan daya tahan tubuh Orang Rimba menjadi lemah dan rentang terserang penyakit, sehingga mengakibatkan kasus kematian. Dalam kasus ini juga memperlihatkan bahwa Orang Rimba membutuhkan hutan sebagai ruang gerak yang cukup tidak hanya sebagai penghidupan semata namun sebagai locus tradisi sebagai salah satu bentuk identifikasi diri identitas suatu etnik. Tradisi melangun menjadi tradisi yang menjadi pembentuk identitas mereka sebagai suatu etnik yang unik dibandingkan dengan kelompok etnik yang lain, yang ada di Jambi.

Dalam konteks ini maka penting untuk dapat memahami Orang Rimba sebagai kelompok masyarakat berburu-meramu dalam mencukupi ketersediaan dan pemenuhan akses pangan mereka untuk merespon situasi Covid-19 yang sesuai dengan preferensi kebudayaan yang mereka miliki. Dapat dikatakan tujuan utama penelitian ini adalah mengetahui dan memahami fenomena ketahanan pangan dalam perspektif Orang Rimba yang dilihat dari ketersediaan, kecukupan, keterjankauan dan keamanan ditengah masa pandemik Covid-19.

\section{B. METODE PENELITIAN}

$\mathrm{P}$ enelitian ini menggunakan pendekatan mikroetnografi dimana merupakan bagian dari metode penelitian kualitatif untuk dapat memahami kondisi ketahanan pangan Orang Rimba. Metode pengumpulan data lapangan menggunakan kombinasi survey, wawancaram diskusi kelompok terfokus dan melakukan observasi di lapangan (Ngoc, H., Thi, D., Chi, L., \& Kingsbury 2019). Lokasi penelitian ini dilaksanakan di wilayah selatan Taman Nasional Bukit Duabelas yang masuk dalam wilayah Desa Bukit Suban, Kecamatan Air Htam, Kabupaten Sarolangun, Propinsi Jambi. Sasaran penelitian ini adalah keluarga Orang Rimba kelompok Njalo yang berada di Sungai Sakoselengsing dimana mereka terdiri dari 10 keluarga. Alasan pemilihan kelompok Njalo ini adalah selain kedekatan peneliti terhadap terhadap informan ${ }^{1}$, juga dikarenakan kelompok Njalo sudah mulai mengkombinasikan sumber penghidupan mereka dari intensifikasi pertanian dan aktivitas berburu dan meramu. Penelitian lapangan dilakukan pada bulan Juni 2020 dengan melakukan observasi dan interview secara mendalam terhadap beberapa narasumber.

Penelitian kualitatif sendiri dapat dipahami sebagai metode penelitian sosial yang menggunakan berbagai macam metode pengumpulan secara materi empiris, studi kasus, pengalaman pribadi, introspektif, catatan kisah hidup, wawancara, analisa teks, observasi, sejarah, interaksional, dan visual, dimana akan menggambarkan momen penting dan makna rutin dalam kehidupan individu (Denzin \& Lincoln 1994). Sedangkan mikroetnografi adalah sebuah pendekatan yang menggambarkan bagaimana interaksi antara peneliti dan informan diatur secara sosial dan budaya dalam situasional tertentu dan dalam rutinitas sehari-hari (Atkinson, D., Okada, H., \& Talmy 2011). Mikroetnografi mencoba menganalisa suatu episode tertentu suatu kelompok masyarakat dimana memberikan pemahaman tentang bagaimana pengetahuan direproduksi, dimaknai, dan digunakan oleh anggota keluarga. Masa pandemik Covid-19 ini bagi penulis telah memberikan konteks episode situasi rutinitas yang berbeda mempengaruhi pengetahuan Orang Rimba, terutama berkaitan dengan bagaimana mereka menjaga kemandirian ketahanan pangan.

\section{HASIL DAN DISKUSI}

\section{Gambaran Umum Orang Rimba Kelompok Njalo}

$\mathrm{O}$ rang Rimba kelompok Njalo merupakan kelompok Orang Rimba yang ada dalam wilayah kepemimpinan Tumenggung Ngrip, yang masuk dalam wilayah Sungai Kedundung Muda. Saat ini mereka mulai melakukan intensifikasi pertanian di sekitar Sungai Sakoselengsing. Sekumpulan keluarga Orang Rimba yang membuat kebun secara bersama-sama inilah yang kemudian menyatakan diri mereka sebagai kelompok Njalo di Sungai Selingsing. Sifat dari pembentukan kelompok ini bersifat cair dan tidak mengikat dimana mereka dapat bergabung dengan kelompok yang laian apabila mereka memiliki kepentingan yang sama misalnya dalam pembukaan kebun maupun kelompok yang khusus untuk berburu dan mengumpulkan hasil hutan.

\footnotetext{
${ }^{1}$ Peneliti telah bekerja sebagai pendamping kelompok Orang Rimba sejak tahun 2008- sekarang sehingga memudahkan untuk memahami tindakan dan tradisi Orang Rimba
} 


\section{Gambaran Sumber Penghidupan Orang Rimba kelompok Njalo}

Anggota Kelompok Njalo terdiri dari 10 kepala keluarga yang secara bersama-sama sedang membuka hutan untuk berkebun. Sebelumnya sebagian besar dari anggota kelompok Njalo tersebar di dalam hutan Kawasan Taman Nasional Bukit Dua belas kurang lebih sekitar tiga bulan terakhir (MaretMei) setelah terdengar kabar adanya pandemik Covid-19 untuk menghindari penyakit tersebut. Ketika suasana sudah mulai tenang, sebagian besar Orang Rimba bergeser ke pinggiran hutan untuk membuka kebun. Lokasi pembukaan kebun berada di sekitar
Sungai Selingsing tersebut kurang lebih berjarak sekitar $1 \mathrm{~km}$ atau berjalan selama 20 menit dari pemukiman setempat. Alasan pembukaan kebun dekat dengan desa menurut Njalo untuk mendekatkan hasil kebun mereka dengan pasar.

Kondisi tersebut dapat dilihat pada grafis dibahwah ini dan dari pernyataan Njalo menyebutkan, "Kami sekarang ada sepuluh keluarga yang berada di sungai Sakoselengsing ini. Kami mau membuka kebun karet sama kebun ubi, ada juga sebagian mau tanam sawit. Sudah setahun lebih kami di situ... sempat kami kabur ke hutan karena takut terkena penyakit... lokasi kami membuka dekat dengan desa agar dekat untuk menjual hasil kebun kami..."

Grafis 1. Jenis Pekerjaan Responden

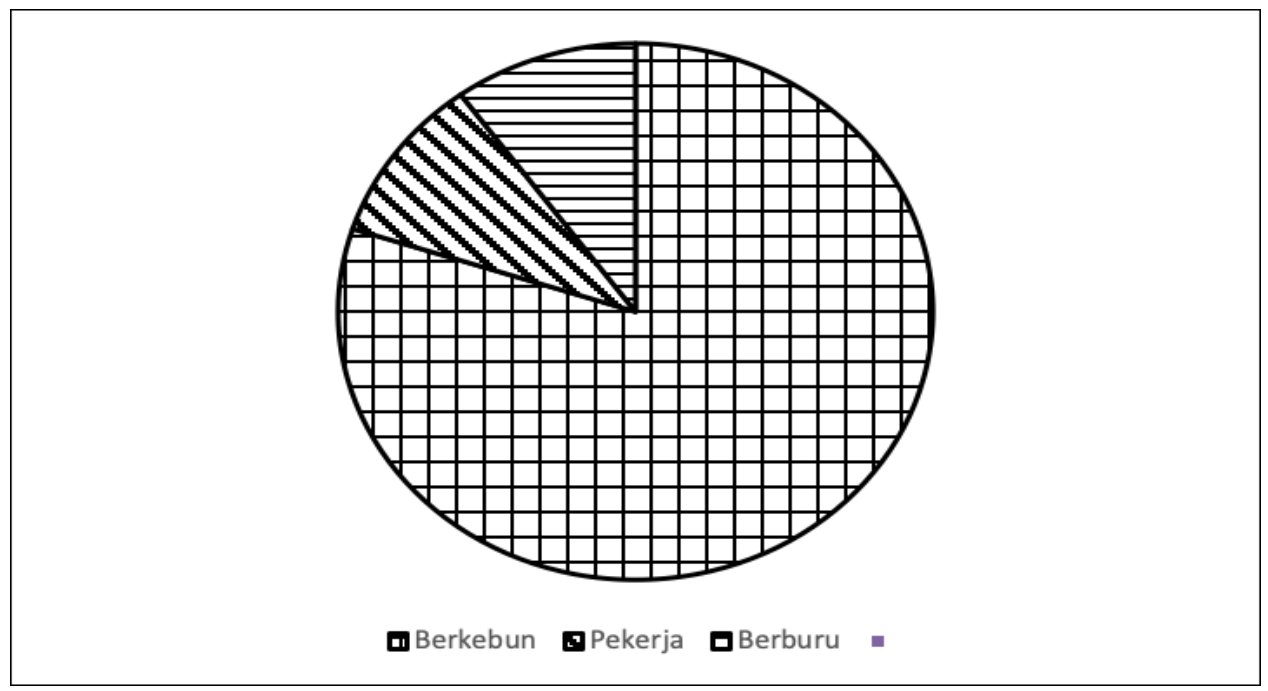

Sumber: Hasil Olah Lapangan oleh Kristiawan (2020)

Grafis 1. diatas menunjuKkan bahwa sebagian besar atau 80 persen Orang Rimba kelompok Njalo melakukan intensifikasi pertanian sebagai sumber penghidupan mereka. Kondisi tersebut sesuai dengan hasil penelitian Kumar et all (2020) yang menunjukkan bahwa cara hidup berladang merupakan bagian dari budaya dan tradisi dari masyarakat adat di India (Kumar, D., De, H. K., Kumar, S., Kumar, B., Dobhal, S., \& Adhiguru 2020).

Meskipun Orang Rimba kelompok Njalo sudah melakukan intensifikasi pertanian, mereka masih mempraktekkan budaya berburu dan meramu. Kegiatan ini mereka lakukan sebagai kegiatan rekresi, untuk mencukupi kebutuhan makanan sehari-hari, dan mengumpulakn hasil hutan yang bernilai ekonomi seperti getah jernang, damar, madu, durian hutan yang mereka jual ke pasar. Situasi tersebut dapat ditemukan pada wawancara dengan Gemambun yang menyebutkan:

"Pekerjaan utama kami ya berkebun karet, ada sebagian sedang mencoba berkebun sawit. Tetapi kami juga masih senang berburu mencari hasil hutan seperti jernang, damar, madu, buah-buahan hutan diamana hasilnya sebagian kami makan dan sebagian kami jual... Hasil penjualan hasil hutan tersebut kami gunakan untuk membeli berbagai bahan makanan seperti gula, kopi, minyak goreng, rokok yang tidak dapat kami penuhi dari hasil hutan" (Kristiawan 2020)

Berdasarkan hasil wawancara tersebut diatas, sifat ketergantungan ekonomi Orang Rimba terhadap hutan masih sangat tinggi. Kondisi tersebut mendorong Orang Rimba untuk tetap mengambil hasil hutan bukan kayu sebagai salah satu alternatif sumber ekonomi mereka. Situasi tersebut sesuai dengan hasil penelitian Mamuko et all yang melakukan penelitian tentang persepsi dan partisipasi masyarakat dalam rehabilitasi hutan dan lahan. Hasil penelitian menunjukkan bahwa semakin tinggi jumlah tanggungan dan kebutuhan keluarga, akan mendorong masyarakat untuk memanfaatkan hasil hutan (Frida Mamuko, H. Walangitan 2016).

Menurut Gemambun dan Njalo, tantangan mendapatkan dan menggantungkan hidup dari hasil hutan adalah semakin semakin sedikitnya luasan hutan, semakin banyaknya orang yang mencari hasil hutan. Selain itu, harga beberapa komoditas yang sangat rendah, dan adanya perubahan musim yang berpengaruh pada produk-produk hutan. Gambaran tantangan Orang Rimba dalam memanfaatkan hasil hutan dapat ditemukan dalam kutipan di bawah ini. 
"tantangannya sekarang ini hutan semakin sempit, orang yang mencari semakin banyak sehingga sering kami berebut... musim yang tidak menentu berpengaruh pada hasil yang kami dapatkan... terkadang harganya mahal jika barang sedikit, jika barang banyak harganya murah... tapi beberapa barang kayak damar dari dulu, sudah sekitar 15 tahun kemi mencari, harganya masih sekitar 2000/kilo, tidak sebanding dengan jauhnya kami mencari dan membawanya ke pinggir desa" (Kristiawan 2020)

Berdasarkan pernyataan tersebut diatas, menunjukkan bahwa hasil hutan sangat dipengaruhi oleh musim. Beberapa hasil hutan yang Dengan demikian, musim ini sangat berpengaruh pada kodisi ekonomi dan berpengaruh pada kerawanan pangan Orang Rimba yang hanya mengandalkan hasil hutan. Pengaruh musim terhadap ketahanan pangan Orang Rimba sesuai dengan hasil penelitian Moraco \& Bhat (2018) yang mengatakan bahwa ketahanan pangan kerentanan ketahanan pangan dapat terjadi karena adanya perubahan iklim dan bencana alam (Shah, S.,Moroca,A.,\& Bhat 2018). Sedangkan hasil penelitian Belinda (2018) menyatakan bahwa hasil karet merupakan hasil hutan yang memiliki nilai ekonomi paling besar dibandingkan hasil hutan bukan kayu lainnya (Yulianti 2018). Berdasarkan kedua penelitian tersebut dapat disimpulkan bahwa pilihan intensifikasi pertanian merupakan pilihan realistis dari Orang Rimba untuk mencukupkan kebutuhan makanan mereka.

\section{Gambaran Pendapatan dan Pengeluaran Orang Rimba Kelompok Njalo}

Rata-rata pendapatan Orang Rimba kelompok Njalo sebesar satu juta sampai satu setengah juta rupiah perbulan. Penghasilan tersebut mereka dapatkan dari aktivitas menyadap karet, menjual hasil pertanian (ubi kayu) dan menjual hutan bukan kayu yang mereka kumpulkan dari hutan sektitar mereka. Jumlah hasil getah karet yang didapatkan Orang Rimba sangat tergantung dari intensitas hujan. Semkin sering terjadi hujan, akan menurunkan kondisi jumlah Orang Rimba menyadap karet.
Sedangkan hasil hutan yang mereka kumpulkan sangat tergantung dari perubahan alam yang berpengaruh pada siklus musim. Seperti misalnya pada musim buah-buahan, Orang Rimba akan mendapatkan hasil madu dan hasil dari berbagai jenis buah-buahan hutan yang dapat mereka jual ke luar. Namun apabila pada musim buah-buahan tersebut, tidak banyak tanaman buah yang berbunga karena kondisi iklim yang tidak menentu, dapat dipastikan Orang Rimba tidak mendapatkan hasil madu dan berbagai jenis buah-buahan dari hutan.

Situasi itu tersirat pada pernyataan Bedingen yang menyebutkan "Jika mengambil hasil dari kebun kami dua minggu sekali, kami menjual getah karet kadang dapat $60 \mathrm{~kg}$, kadang dapat $80 \mathrm{Kg}$. Itu tergantung pada musim juga. Jika musim penghujan kurang dari 50 kg/ bulan, jika musim hujan tidak ada dapatlah. Jika harga karet sekarang sekitar 6000/ kg. Kadang kami jual ubi kayu ke desa untuk dapat uang... Kalo hasil hutan tidak dapat dipastikan, misalnya musim buah bagus, kami pasti dapat hasil madu banyak dan hasil buah hutan berlimpah... kadang kami juga mencari sampai jauh ke daerah lain yang jarang di akses Orang Rimba untuk mendapatkan hasil hutan tersebut...Untuk madu hutan dapat kami jual 80 ribu/ kilo... kadang ada yang sampai 100 ribu/kilo, madu kami mahal karena asli dari hutan tidak kami campur-campur... kami jual ke orang desa... setelah beberapa bulan kami juga bisa menjual buah hutan seperti durian hutan, cempedak itu orang desa mau membelinya" (Kristiawan 2020)

Berdasarkan kutipan tersebut diatas, penentu tinggi rendahnya pendapatan Orang Rimba yang berkaitan dengan akvitas perburuan dan pencarian hasil hutan sangat ditentukan oleh luasan area dan musim. Semakin jauh lokasi berburu dan pencarian, akan berkorelasi dengan hasil buruan.

Pengeluaran terbesar rumah tangga Orang Rimba sendiri adalah konsumsi rokok dan kebutuhan jajanan pasar untuk anak-anak. Rata-rata pengeluaran rumah tangga Orang Rimba kelompok Njalo dapat terlihat pada Tabel 1 berikut ini.

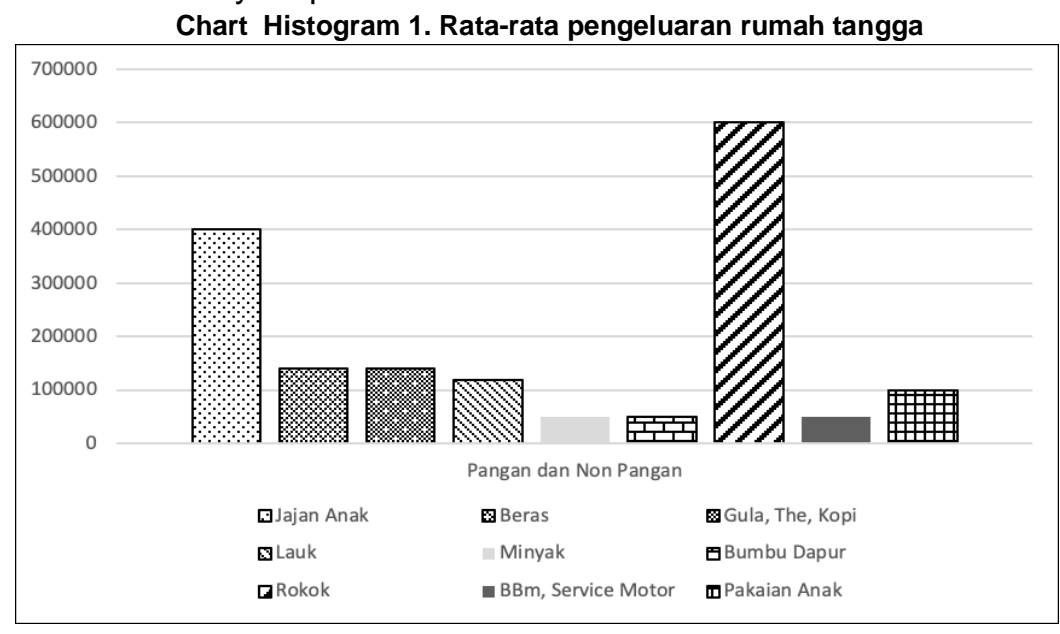

Sumber: Hasil Olah Lapangan oleh Kristiawan (2020)

$86 \mid \mathrm{P}$ a g e 
Berdasarkan Chart Histogram 1 di atas, rata-rata pengeluaran rumah tangga Orang Rimba Kelompok Njalo adalah konsumsi rokok dan jajanan anakanak. Menurut Induk Bebungo (Beraden) dalam sehari, suaminya dapat menghabiskan 1-2 bungkus rokok. Konsumsi rokok tersebut dapat meningkat pada kondisi misalnya mereka sedang mengikuti kegiatan rapat adat atau sedang tidak bekerja. Jenis dan harga rokok yang disukai dan konsumsi suaminya, dimana rata-rata seharga 12 sampai 25 ribu/ bungkus. Pengeluaran terbesar kedua mereka adalah untuk membeli jajanan untuk anak-anak. Menurut induk-induk, ketika anak-anak menangis meminta jajan dan orang tua tidak dapat memenuhinya, anak akan menangis terus menerus. Situasi itu dapat menimbulkan rasa malu bagi orang tua anak tersebut.

Pernyataan tersebut dibenarkan juga oleh Induk Nyerat dan Induk Bepuncak yang menyebutkan" Kami yang merokok rata-rata sebungkus sehari, ada juga yang sampai tiga bungkus sehari. Kalau kami sedang ada musyawarah adat atu sedang tidak bekerja kami bisa habiskan sampai empat bungkus sehari...sebungkus harganya ada ada yang 12 ribu/bugkus ada yang 20 ada yang 25ribu/bungkus tergantung kesenangan masing-masing................. pengeluaran lainnya adalah untuk jajan anak... Tiap hari anak itu meminta uang jajan... sehari kadang habis 10 ribu kadang habis 12 ribu untuk setiap anak... Jika tidak diberi anak menangis terus. Kami orang tua malu sama yang lain melihat kelakuan anak kami...Jika untuk makan, kami tidak pusing selama masih ada ubi kayu dan garam... ubi kayu dapat kami rebus beserta lauk ikan atau hewan buruan di tambah dengan garam sudah cukup... tapi jika tidak ada rokok, bisa kami ribut di rumah... jika sudah mentok sekali tidak ada uang, kami datang ke toke untuk nyari pinjaman untuk beli rokok..." (Kristiawan 2020)

Berdasarkan hasil kutipan dan tabel tersebut diatas, pengeluaran terbesar harian Orang Rimba adalah untuk pemenuhan kebutuhan sekunder seperti rokok, jajan anak. Sedangkan pemenuhan kebutuhan pokok seperti makanan beserta lauk pauknya masih dapat mereka penuhi dari pasar. Pada konteks ini, Orang Rimba telah dapat memenuhi aspek ketersediaan pangan dan akses pangan.

\section{Gambaran ketahanan Pangan Kelompok Njalo pada masa Pandemik Covid19}

Organisasi pangan dunia (FAO) mendeskripsikan ketahanan pangan adalah kondisi dimana individu atau rumah tangga menerima akses secara fisik ataupun ekonomi untuk mendapatkan pangan bagi seluruh anggota rumah tangga dan tidak berisiko kehilangan keduanya (Food and Agriculture Organization 2016). Sedangkan menurut UU No 8 tahun 2012 tentang pangan, telah dijelaskan beberapa konsep mengenai kedaulatan pangan, kemandirian pangan, ketahanan pangan, keamanan pangan, produksi pangan dan ketersediaan pangan. Ketahanan pangan didefiniskan sebagai kondisi terpenuhinya pangan bagi negara sampai dengan perorangan, baik jumlah maupun mutunya, aman, merata, beragam, bergizi, terjangkau, tidak bertentangan dengan agama, aktif, sehat dan produktif secara berkelanjutan (Peraturan Presiden 2012).

Fraanje \& Lee-Gammage (2018) mendefinisikan ketahanan pangan adalah suatu konsep yang digunakan untuk berpikir secara sistematis tentang bagaimana dan mengapa kondisi malnutrisi muncul, dan tindakan apa yang bisa dilakukan untuk mengatasi dan mencegahnya. Ketahanan pangan juga sebagai suatu ideologi moral yang bisa dilihat bahwa penyediaan pangan sebagai pemenuhan hak asasi manusia (Fraanje, W., \& Lee_Gammage 2018).

Ketahanan pangan merupakan sistem ekonomi pangan yang terdiri dari beberapa sub sistem yang saling terintergrasi satu dengan yang lainnya. Sub sistem yang dimaksud adalah ketersediaan pangan, distribusi pangan dan konsumsi pangan. Ketahanan pangan merupakan kebutuhan yang paling dasar bagi manusia sehingga pangan sangat berperan dalam pertumbuhan ekonomi nasional. Oleh karena itu peningkatan ketahanan pangan merupakan prioritas utama dalam pembangunan nasional (Doremus 2019).

Pada pertengahan 1970-an, wacana tentang ketahanan pangan difokuskan pada kebutuhan untuk berproduksi lebih banyak makanan dan bagaimana untuk mendistribusikannya dengan lebih baik. Oleh karena itu diskusi tentang ketahanan pangan diprioritaskan pada produksi dan ketersediaan pangan saja. Terdapat tiga aspek penting sebagai indikator keberhasilan peningkatan ketahanan pangan. Ketigas aspek tersebut adalah food availability, food access, food utilization (Saragih 2010).

Namun seiring berjalannya waktu, konsep ketahanan pangan telah diperluas hingga mencakup faktor yang dapat mempengaruhi malnutrisi di seluruh makanan, sistem dan dalam beberapa implementasinya adalah termasuk besarnya peran sosial dan budaya suatu masyarakat dalam makanan. Dalam konteks kekinian, konsep ketahanan pangan secara umum dapat dipahami dalam empat komponen utama, yaitu berkaitan dengan ketersediaan, akses, pemanfaatan, dan stabilitas; dimana dalam kondisi ketahanan pangan ada, semua komponen ini harus tersedia secara memadai (Fraanje, W., \& Lee_Gammage 2018).

Ketersediaan pangan berkaitan dengan pemenuhan pangan untuk masyarakat yang cukup bergizi dengan kualitas yang baik, dimana ketersediaan tersebut dapat dipenuhi oleh produksi seperti berapa banyak dan jenis makanan apa yang tersedia melalui makanan yang diproduksi dan disimpan secara lokal, kemudian distribusi atau 
bagaimana makanan tersedia (dipindahkan secara fisik) dalam bentuk apa, kapan, dan kepada siapa, dan juga faktor pertukaran yang berkaitan dengan berapa banyak makanan yang tersedia dapat diperoleh melalui mekanisme pertukaran seperti barter, perdagangan, pembelian, atau pinjaman oleh masyarakat tersebut.

Lalu akses makanan dimana berkaitan dengan bagaimana individu dan rumah tangga dapat memperoleh makanan yang cukup dengan pola makan yang sehat, bergizi, atau memiliki akses ke sumber daya yang cukup yang dibutuhkan untuk menanam makanan mereka sendiri. Akses ini dapat dipengaruhi oleh beberapa faktor, yaitu antara lain adalah keterjangkauan bagaimana kemampuan individu, rumah tangga atau komunitas untuk membeli makanan atau harga tanah untuk memproduksi makanan, relatif terhadap pendapatan mereka. Kemudian bagaimana alokasi sumber daya berkaitan dengan mekanisme ekonomi, sosial dan politik yang mengatur kapan, dimana, dan bagaimana makanan dapat diakses oleh konsumen. Selain itu adalah preferensi makanan tertentu berkaitan dengan norma dan nilai sosial, agama, dan budaya yang mempengaruhi permintaan konsumen akan jenis makanan tertentu (misalnya larangan agama atau keinginan untuk mengikuti pola diet tertentu seperti vegetarianisme).

Fraanje \& Lee-Gammage (2018) juga menjelaskan bahwa pemanfaatan pangan berkaitan dengan bagaimana masyarakat memiliki akses ke jumlah dan keragaman makanan yang cukup untuk memenuhi kebutuhan nutrisinya, serta metabolisme makanan tersebut dengan benar. Dan stabilitas makanan yang berhubungan dengan ketersediaan makanan yang dapat diakses oleh orang-orang yang mampu memanfaatkannya secara efektif, namun juga bagaimana memenuhinya secara permanen dan konsisten.

Dalam konteks ini, seperti diungkapkan oleh Fraanje \& Lee-Gammage (2018), bahwa pemenuhan makanan dan ketahanan pangan bukanlah permasalahan makanan saja tetapi juga bagaimana negara memastikan warganya untuk mendapatkan makanan sesuai dengan standard yang telah ditetapkan (Fraanje, W., \& Lee_Gammage 2018). Berkaitan dengan ini maka bisa disebutkan bahwa ketahanan pangan juga berkaitan dengan pemenuhan hak azasi manusia. Bagaimana negara juga memastikan bahwa warga mendapatkan akses makanan, produksi makanan, dan sesuai dengan preferensi budayanya

Makanan utama Orang Rimba Kelompok Njalo adalah ubi kayu. Mereka menyukai konsumsi ubi kayu karena ubi kayu dapat membuat mengenyangkan dalam waktu lama. Selain ubi kayu, Orang Rimba masih memanfaatkan umbi-umbian yang alami tumbuh di hutan seperti benor dan gadung. Namun umbi-umbian hutan tersebut sudah jarang mereka konsumsi karena jumlah ubi hutan yang mulai sulit didapatkan serta pengolahan ubi tersebut membutuhkan pengolahan yang lebih rumit dibandingkan ubi kayu. Menurut induk-induk, keunggulan ubi mudah tumbuh, mudah ditanam, dapat disimpan jangka waktu yang lama sebelum dikonsumsi, dan dapat dijual ke masyarakat desa.

Pernyataan tersebut dikuatkan oleh Induk Matut dan Induk Nentu sebagai berikut, "Kami menyukai ubi kayu. Kalo menurut makanan nenek moyang senanglah makan ubi kayu, ubi kayu itu kami tanam sendiri. Kami juga kadang masih makan umbiumbian dari hutan kayak benor dan gadung, tapi pengolahannya agak payah kini. Jumlah umbiumbinya juga sudah mulai jarang karena hutan semakin menyempit. Kalo ubi kayu mudah tumbuhnya, pengolahannya mudah. Jika kami mau menjual ubi kayu ke orang desa mereka mau membelinya... jadi kami juga dapat membeli garam, gula, kopi, teh dari penjualan ubi tersebut" (Kristiawan 2020)

Berdasarkan kutipan diatas, Orang Rimba kelompok Njalo sudah dapat memproduksi kebutuhan makanan pokok secara mandiri. Dengan demikian Orang Rimba kelompok Njalo telah dapat memenuhi kebutuhan makanan dari ketersediaan dan akses pangan. Sedangkan untuk pemenuhan kebutuhan lainnya seperti garam, gula, kopi dan minyak mereka mendapatkan dari menjual ubi kayu hasil pengolahan mereka.

Disisi lain dalam konsep ketahanan pangan, Orang Rimba mempraktekkan budaya pantang'on. Makna dari budaya tersebut mereka menjalankan berbagai pantangan mengkonsumsi makanan yang berasal dari binatang peliharaan yang dipelihara oleh Orang Melayu seperti: ayam, telur, kambing, sapi, dan susu. Makanan ini bagi Orang Rimba mewakili kehidupan Orang Terang. Hal ini berkaitan dengan kepercayaan mereka tentang asal-usul mereka dengan masyarakat Melayu pada umumnya (Prasetijo 2011).

Pada perkembangan beberapa kelompok Orang Rimba saat ini pantangan-pantangan tersebut juga sudah mulai perubahan. Mereka mulai mengkonsumsi makanan dai luar yang didapatkan, baik dai bantuan ataupun membeli, tradisi ini membentuk preferensi Orang Rimba dalam mengkonsumsi makanan. Misalnya mereka menilai bahwa daging babi masih lebih enak rasanya jika dibandingkan dengan daging sapi, atau daging ayam yang rasanya bagi mereka hambar jika dibandingkan dengan daging burung kuo atau ayam hutan. Kondisi tersebut menegaskan bahwa kebiasaan dan pola makan masyarakat adat sangat terkait dengan budaya, kepercayaan dan patangan makanan (Nurti 2017).

Pada masa Pandemik Covid-19, sebagian besar Orang Rimba dan kelompok Njalo masuk ke hutan karena sangat ketakutan tertular oleh penyakit tersebut. Tujuan masuk ke hutan adlaah memisahkan diri dari sumber penularan penyakit dan mencari sumber makanan di dalam hutan. Dalam konsep budaya Orang Rimba istilah mencegah penularan penyakit merupakan budaya 
turun temurun yang mereka sebut besesandingon2. Pada masa tersebut, setiap anggota Orang Rimba yang terkena penyakit seperti batuk, pilek maupun demam akan mereka pisahkan dari kelompok Orang Rimba yang yang masih sehat. Pada saat menjalankan budaya besesandingon sebagian Orang Rimba melakukan aktivitas membuka hutan sebagai kebun sebagai sumber makanan pokok mereka.

Menurut Orang Rimba Kelompok Njalo, ketakutan mereka akan penyakit ini sangat luar biasa sekali. Mereka belum pernah mendengar sebelumnya terdapat penyakit yang dapat menyebar di seluruh dunia dan banyak menimbulkan kematian. Mereka menganggap apabila banyak orang di dunia ini yang meninggal karena penyakit ini, bukan tidak mungkin Orang Rimba juga kana musnah terbunuh oleh penyakit ini.

Ketakutan dan sikap Orang Rimba pada masa Covid-19 ini terlihat dalam pernyataan Njalo dan beberapa angota kelompoknya seperti berikut: "kami sangat ketakutan Ketika mendengar mengenai penyakit ini... kabarnya dari orang desa penyakit ini telah membunuh orang-orang di dunia jadi kami sangat ketakutan... bisa musnah kami... untuk menjauhkan dari penyakit, kami lari ke hutan, kami besesanding, kami melarang orang lain masuk, kalo ada yang baru keluar kami pisahkan. Jika ada yang muncul tanda saki-sakit, kami pisahkan...kami lari ke hutan semua berhamburna kami... kami tinggalkan kebun kami yang belum jadi ini...di hutan kami mencari makan dengan berburu ada yang membuka hutan untuk berkebun ubi... selama kami berdiam di hutan kami juga bisa menyadap kebun karet yang sudah lama kami tinggalkan karena jauh menjual hasil getahnya" (Kristiawan 2020)

Pada masa pendemik dimana banyak masyarakat mengalami kesulitan pangan, disisi lain Orang Rimba justru terdorong untuk mengolah kebun sebagai sumber makanan pokok mereka. Dengan demikian untuk konteks Orang Rimba kelompok Njalo tidak mengalami kekurangan makanan pokok, namun justru mereka mengalami gangguan pskologis ganguan rasa aman akibat pandemik Covid-19.

Persoalan lain selain gangguan rasa aman adalah berkurangnya sumber pendapatan Orang Rimba untuk mencukupi kebutuhan sekunder. Kebutuhan ini biasa mereka cukupkan dari menjual hasil hutan dan menjual hasil buruan. Pada masa ini, sebagian Orang Rimba tidak berani melakukan aktivitas berburu ke wilayah lain karena takut bertemu dengan orang lain. Ketika Orang Rimba mendapatkan hasil buruanpun, beberapa pengumpul hasil buruan juga menolak membeli hasil

\footnotetext{
2 Besesandingon atau sesanding merupakan tradisi Orang Rimba untuk mencegah penularan penyakit dengan memisahkan orang yang habis bepergian dan berjumpa dengan orang luar dan dianggap dapat membawa penyakit ke kelompok mereka. Sasanding ini biasanya berlangsung selama 3-4 hari, atau bisa juga sampai terbukti tidak membawa penyakit.
}

buruan karena distribusi dari hasil buruan juga terhenti.

Kondisi tersebut dapat ditemukan pada pernyataan dari Bungo yang merupakan Orang Rimba yang intensif melakukan aktivitas berburu dibandingkan Orang Rimba lainnyha di Kelompok Njalo "kami sudah jarang berburu sekarang, kaluapun berburu hanya sekitar sini saha... kami takut bertemu orang, kami takut tertular penyakit dari orang desa. Toke ${ }^{3}$ penampung kami membatasi pembelian. Stock daging masing banyak. Kata pengumpul dagingnya pengiriman daging lagi macet pada masa pandemik ini... jadi kami payah untuk membeli rokok sekarang... paling-paling kami jual ubilah ke desa..." (Kristiawan 2020)

Berdasarkan hasil kutipan tersebut diatas, tantangan utama Orang Rimba dalam masa ini adalah pemenuhan kebutuhan rasa aman dan pemenuhan kebutuhan sekunder Orang Rimba yang harus mereka datangkan dari pasar. Salah satu solusi yang mereka lakukan untuk pemenuhan rasa aman adalah masuk ke hutan dan mengisolasi diri di dalam hutan. Sedangkan untuk pemenuhan kebutuhan sehari-hari yang harus mereka datangkan dari pasar dilakukan dengan cara menjual hasil kelebihan sumber makanan pokok mereka berupa ubi kayu.

\section{Analisa Adaptasi Pemenuhan kebutuhan Orang Rimba Kelompok Njalo Pada Masa Pandemik Covid-19}

Pola adaptasi Orang Rimba pada masa pandemik Covid-19 adalah melakukan isolasi sosial dan masuk ke dalam hutan kawasan TNBD. Pada lokasi tersebut Orang Rimba dipaksa untuk melakukan reproduksi pengetahuan guna memenuhi kebutuhan sehari-hari. Selain melakukan reproduksi pengetahuan, Orang Rimba juga melakukan penyesuaian tingkat kebutuhan dan dianggap tidak perlu mereka lakukan selama di dalam hutan. Berikut ini terdapat tabel orientasi perubahan kebutuhan Orang Rimba pada sebelum pandemik dan semasa pendemik.

\footnotetext{
${ }^{3}$ Toke merupakan pengumpul hewan buruan seperti babi yang kemudian mendistribusikan daging tersebut ke wilayah jawa dan ke wilayah Sumatra Utara.
} 
Tabel 1. Analisa Kebutuhan Orang Rimba Sebelum dan Semasa Pandemik

\begin{tabular}{|c|c|c|c|c|c|c|c|}
\hline \multirow[b]{2}{*}{ No } & \multirow{2}{*}{$\begin{array}{l}\text { Kebutuhan } \\
\text { Orang Rimba }\end{array}$} & \multicolumn{3}{|c|}{ Sebelum Pandemik } & \multicolumn{3}{|c|}{ Semasa Pandemik } \\
\hline & & Sumber & $\begin{array}{c}\text { Cara } \\
\text { Mendapatkan }\end{array}$ & $\begin{array}{c}\text { Tingkat } \\
\text { Kebutuhan }\end{array}$ & Sumber & $\begin{array}{c}\text { Cara } \\
\text { Mendapatkan }\end{array}$ & $\begin{array}{c}\text { Tingkat } \\
\text { Kebutuhan }\end{array}$ \\
\hline \multirow[t]{7}{*}{1} & \multicolumn{7}{|c|}{ Makanan dan Minuman } \\
\hline & \multirow[t]{2}{*}{$\begin{array}{l}\text { Sumber } \\
\text { karbohidrat }\end{array}$} & Beras & Membeli & Sedang & Beras & Bantuan & Sedang \\
\hline & & Ubi Kayu & Tanam Sendiri & Tinggi & Ubi Kayu & Tanam Sendiri & Tinggi \\
\hline & \multirow[t]{2}{*}{$\begin{array}{l}\text { Sumber } \\
\text { protein }\end{array}$} & Ikan & $\begin{array}{l}\text { Membeli; } \\
\text { Mencari }\end{array}$ & Tinggi & Ikan & $\begin{array}{l}\text { Mencari di } \\
\text { Sungai }\end{array}$ & Tinggi \\
\hline & & Daging & Berburu & Tinggi & Daging & Berburu & Tinggi \\
\hline & Gula, Kopi & Pasar & Membeli & Tinggi & $\begin{array}{l}\text { Pasar, } \\
\text { Mengumpul } \\
\text { kan hasil } \\
\text { hutan }\end{array}$ & Membeli & Sedang \\
\hline & $\begin{array}{l}\text { Minyak } \\
\text { Makan }\end{array}$ & Pasar & Membeli & Sedang & $\begin{array}{l}\text { Minyak } \\
\text { Hewani }\end{array}$ & $\begin{array}{l}\text { Mengolah lemak } \\
\text { hewan }\end{array}$ & Rendah \\
\hline
\end{tabular}

Beras bukan merupakan makanan pokok Orang Rimba. Pada masa pandemik ini, Orang Rimba tidak membeli beras sebagai salah satu cara untuk mengurangi pengeluaran Orang Rimba. Pada masa pendemik, Orang Rimba memiliki waktu luang untuk membuka ladang kebun ubi sebagai sumber makanan pokok mereka. Perluasan kebun ubi yang berdampak pada hasil dapat menjadi sumber pendapatan keluarga.

Migrasi dan isolasi sosial Orang Rimba ke dalam hutan memberikan peluang mereka untuk mandapatkan berbagai jenis ikan sungai di dalam kawasan hutan.

Migrasi dan isolasi sosial Orang Rimba ke dalam hutan memberikan peluang mereka untuk mandapatkan berbagai jenis hewan buruan hutan.

Kebutuhan minuman berupa gula dapat digantikan oleh madu hutan dan air tebu, sedankan kebutuhan kopi mereka tetap harus datangkan dari pasar Kebutuhan minyak makan dapat dipenuhi dari memanfaatkan minyak yang bersumber dari lemak hewan terutama babi hutan. Sebagai konsekuensi minimnya minyak ini, kemudian Orang Rimba mulai mengurangi konsumsi dari minyak makan ini.

\begin{tabular}{|c|c|c|c|c|c|c|c|c|}
\hline & Bumbu Dapur & Pasar & Membeli & Sedang & Pasar & Membeli & Rendah & $\begin{array}{l}\text { Pada masa pendemic ini, Orang Rimba } \\
\text { hanya menggunakan bumbu masak } \\
\text { garam dan masako sebagai bumbu } \\
\text { masakan mereka }\end{array}$ \\
\hline 2 & Rokok & Pasar & Membeli & Tinggi & $\begin{array}{l}\text { Pasar, } \\
\text { tembakau } \\
\text { tradisional }\end{array}$ & $\begin{array}{l}\text { Membeli, } \\
\text { mencari di hutan }\end{array}$ & Tinggi & $\begin{array}{l}\text { Adanya ketakutan Orang Rimba } \\
\text { berinteraksi dengan masyarakat luar dan } \\
\text { minimnya pemasukan dari menjual hasil } \\
\text { hutan dan menjual ubi, mengharuskan } \\
\text { Orang Rimba mengkombinasikan rokok } \\
\text { yang dibeli dengan rokok tradisional yang } \\
\text { telah lama mereka tinggalkan }\end{array}$ \\
\hline 3 & Jajan Anak & Pasar & Membeli & Tinggi & Pasar & Membeli & Rendah & $\begin{array}{l}\text { Migrasi dan isolasi sosial Orang Rimba ke } \\
\text { dalam hutan menjauhkan anak dari } \\
\text { jajanan pasar dan dan justru mendorong } \\
\text { mereka banyak melakukan aktivitas } \\
\text { bermain dalam hutan. }\end{array}$ \\
\hline 4 & $\begin{array}{l}\text { BBM, service } \\
\text { motor }\end{array}$ & Pasar & Membeli & Tinggi & Pasar & Membeli & Rendah & $\begin{array}{l}\text { Proses isolasi di dalam hutan telah } \\
\text { mengurangi kebutuhan mobilisasi Orang } \\
\text { Rimba sehingga kebutuhan BBM dan } \\
\text { Service motor menjadi berkurang }\end{array}$ \\
\hline 5 & Pakaian anak & Pasar & Membeli & Sedang & Pasar & Membeli & Rendah & $\begin{array}{l}\text { Lokasi isolasi sosial dan pemukiman yang } \\
\text { berada di dalam hutan serta minimnya } \\
\text { interaksi Orang Rimba ke desa, } \\
\text { mendorong mereka sering menggunakan } \\
\text { pakaaian adat berupa kain panjang, } \\
\text { sehingga kebutuhan pakaian anak dapat } \\
\text { berkurang. }\end{array}$ \\
\hline
\end{tabular}

Sumber: Hasil Olah Lapangan oleh Kristiawan (2020)

Berdasarkan Tabel Analisa Kebutuhan Orang Rimba Sebelum dan semasa Pandemik diatas, pola adaptasi yang dilakukan Orang Rimba kelompok Njalo adalah memaksimalkan potensi hutan untuk mencukupi kebutuhan sehari-hari mereka. Selain itu, Orang Rimba juga melakukan perubahan orientasi tingkat kebutuhan non pangan dari tinggi ke sedang dan dari sedang ke orientasi tingkat kebutuhan rendah. 


\section{KESIMPULAN}

$\mathrm{P}$ enelitian ini memberikan kontribusi kepada pemahaman bagaimana kelompok masyarakat berburu-meramu seperti Orang Rimba terdampak pandemik Covid-19, dan bagaimana mereka merespon situasi ini.

Jika kita mengacu kepada Fraanje, W., \& LeeGammage (2018) maka dalam memenuhi ketersediaan dan akses terhadap makanan, sumber penghidupan utama kelompok Njalo mengandalkan dari intensifikasi pertanian dan mengumpulkan hasil hutan non-kayu atau buruan. Temuan menarik dari studi mikroetnografi ini dapat diketahui bahwa mereka kemudian mengkombinasikan dengan kegiatan berburu dan meramu dalam memenuhi ketersediaan pangan dan akses terhadap makanan yang dapat Orang Rimba hasilkan sendiri maupun harus mereka datangkan dari pasar.

Dalam kondisi pandemik seperti ini, Orang Rimba kemudian mereproduksi kembali pengetahuan mereka yaitu budaya membuka hutan untuk pertanian. Awalnya, pandemik covid 19 ini telah menimbulkan keresahan pada anggota kelompok Orang Rimba. Namun disisi lain keresahan tersebut juga memberi peluang waktu mereka selama isolasi kedalam hutan untuk melakukan perluasan kebun ubi sebagai sumber makanan pokok mereka. Ketergantungan dan kebutuhan tertinggi non pangan Orang Rimba berupa rokok telah diantisipasikan Orang Rimba dengan mengkobinasikan tembakau tradisional yang berasal hasil hutan, begitu juga dengan kebutuhan non pangan lainnya mereka mulai mekakukan pengaturan skala prioritas untuk mengurangi pengeluaran keluarga.

Dari studi mikroetnografi keluarga Njalo ini, ketahanan pangan Orang Rimba mempunyai daya resiliansi atau kelenturan sosial dimana mereka mampu mengolah kembali ingatan dan penglaman yang terkapsulasi dalam pengetahuan. Kondisi pandemik ini kemudian mendorong Orang Rimba untuk mereproduksi kembali pengetahuan tersebut dan memperkuat ketahanan pangan mereka.

\section{E. UCAPAN TERIMAKASIH}

erima kasih kami ucapkan kepada Orang
Rimba Kelompok Njalo yang telah bersedia
sebagai narasumber meskipun masih dalam
suasana besesanding.

\section{DAFTAR PUSTAKA}

Atkinson, D., Okada, H., \& Talmy, S. 2011. COntinuum Companion to discourse analysus Ethnography and Discourse Analysis. In K. Hyland \& B. Paltridge (Eds.). London.

Denzin \& Lincoln. 1994. Handbook of Qualitative Research. Loncon: Sage.

Doremus, J. 2019. "Unintended Impacts from Forest Certification : Evidence from Indigenous Aka Households in Congo." Ecological Economics 166 (June). https://doi.org/10.1016/j.ecolecon.201\%0A9.106378.

Food and Agriculture Organization. 2016. Indonesia and FAO Partnering for Food Security and Sustainable Agricultural Development.

Fraanje, W., \& Lee_Gammage, S. 2018. "What Is Food Security?(Foodsource:Building Blocks)." Food Climate Research Network.

Frida Mamuko, H. Walangitan, W. Tilaar. 2016. "Persepsi Dan Partisipasi Masyarakat Dalam Upaya Rehabilitasi Hutan Dan Lahan Di Kabupaten Bolaang Mongondow Timur." Eugenia 22. https://ejournal.unsrat.ac.id/index.php/eugenia/article/view/12959.

Khairunnisa, Syifa Nuri. 2020. "Ketahanan Pangan Dunia Terdampak Pandemi Covid-19." Kompas.com. https://www.kompas.com/food/read/2020/10/13/210700175/ketahanan-pangan-dunia-terdampakpandemi-covid-19?page $=$ all.

Komunitas Konservasi Indonesia (KKI) Warsi. 2019. "Kerusakan Ekosistem, Jambi Rugi Lebih RP 17 T." https://warsi.or.id/kerusakan-ekosistem-jambi-rugi-lebih-rp-17-t/.

Kristiawan. 2020. Wawancara Orang Rimba 3-7 Juni 2020.

Kumar, D., De, H. K., Kumar, S., Kumar, B., Dobhal, S., \& Adhiguru, P. 2020. "Indigenous People' s Attachment to Shifting Cultivation in the Eastern Himalayas, India: A Cross-Sectional Evidence." Forest Policy and Economics 111. https://doi.org/10.1016/j.forpol.2019.1\%0A02046.

Ngoc, H., Thi, D., Chi, L., \& Kingsbury, A. 2019. "Indigenous Knowledge Climate Change Adaptation of Ethnic Minorities in the Mountainous Regions of Vietnam : A Case Study of the Yao People in Bac Kan Province." Agricultural Systems 176(July)1. https://doi.org/10.1016/j.agsy.2019.102683.

Nurti, Yevita. 2017. "Kajian Makanan Dalam Perspektif Antropologi." Antropologi: isu-isu Sosial Budaya 19 (1).

Peraturan Presiden. 2012. Undang-Udang Republik Indonesia No 18 Tahun 2012: Undang-Undang Tentang Pangan. Jakarta.

Prasetijo, Adi. 2011. Serah Jajah Dan Perlawanan Yang Tersisa: Etnografi Orang Rimba Di Jambi. Jakarta: Wedatama Widyasastra. 
2017a. "Livelihood Transformations of the Orang Rimba as Tacit Resistance in the Context of Deforestation." Endogami: Jurnal IImiah Kajian Antropologi 1(1): 1. https://ejournal.undip.ac.id/index.php/endogami/article/view/16829.

2017b. "Living Without the Forest: Adaptive Strategy of Orang Rimba ." Senri Ethnological Studies 95(Sedentarization among Nomadic Peoples in Asia and Africa): 255-78.

Saragih, B. 2010. Suara Agribisnis. Jakarta: PT. Permata Wacana Lestari.

Shah, S.,Moroca,A.,\& Bhat, J.A. 2018. "Neo-Traditional Approches for Ensuring Food Security in Fiji Island." Environmental Deevelopment. httpas://doi.org/10.1016/j.envdev.20018.11.001.

Tambunan, Irma. 2015. "Kematian Orang Rimba Karena Kelaparan." Kompas.com. https://nasional.kompas.com/read/2015/03/04/16292381/Kematian.Beruntun.Orang.Rimba.karena.Kel aparan.

Yulianti, Belinda Hastari \& Reri. 2018. "Pemanfaatan Dan Nilai Ekonomi Hasil Hutan Bukan Kayu Di KPHL Kapuas-Kahayan.” Hutan Tropis 6. https://ppjp.ulm.ac.id/journal/index.php/jht/article/view/5402. 